DOl: 10.5433/2236-2207.2018v9n2suplp43

\title{
O design e seus desafios
}

\author{
Design and its challenges
}

VIDELA, Ana Neuza Botelho

Universidade Federal do Cariri - UFCA I ana.videla@ufca.edu.br

\begin{abstract}
Resumo
A proposta dessa comunicação é refletir sobre as questões que permeiam a constituição do design como um processo social e suas consequências para a forma em que vivemos. A partir do século XVIII, com a Revolução Industrial, aconteceram transformações marcantes para a história da humanidade. Como o design despontou a partir desses acontecimentos, seu surgimento está, portanto, relacionado a um determinado estágio da história do capitalismo e teve um papel fundamental na criação da riqueza industrial. No entanto, com o decorrer do tempo, a atuação da disciplina foi ampliada, ou seja, o design deixou de se ocupar com a aparência das coisas projetadas por engenheiros e cientistas, passando a atuar em outros universos, tais como: cidades, paisagens, nações, corpos, genes, e conforme Latour vai defender, até mesmo na própria natureza. Como reflexo dessa

\section{Abstract}

The purpose of this paper is to reflect on issues about the comprehension of design as a social process and how it influences the way we live. Since the Industrial Revolution in the eighteenth century, major transformations have occurred in the history of humanity. Design emerged from these events and, therefore, it is specifically related to a certain stage of the history of capitalism. Also, design played a fundamental role in increasing the industrial wealth. Over time, however, its comprehensiveness has expanded, that is, instead of the exclusive concern with the appearance of things designed by engineers and scientists, the design started to explore new universes, such as cities, landscapes, nations, bodies, genes, and, according to Latour, even nature itself. As a reflection of this expansion, the way we interact with objects is substancially different.
\end{abstract} ampliação do design, observa-se mudanças na forma como interagimos com os objetos.

Palavras Chave: Design. Filosofia do design. Mundo artificial.

Keywords: Design. Design philosophy. Artificial world.

Projética, Londrina, v.9, n.2 supl. p. 43-58, nov. 2018 


\section{DESIGN}

A proposta dessa comunicação érefletir sobre as questões que permeiam a constituição do design como um processo social e suas consequências para a forma em que vivemos. Historicamente, foram as transformações operadas a partir da Revolução Industrial que criaram as condições para as mudanças na forma de produção de bens de consumo. Embora a intenção aqui não seja a de traçar a história da industrialização, entende-se que destacar os aspectos mais significativos dessas mudanças vai nos auxiliar a compreender o contexto pelo qual a disciplina se constituiu e sua progressiva transformação, até chegar a expansão abarcada pelo design na contemporaneidade. Portanto, uma das características mais marcantes para o surgimento do design foi a fragmentação da tarefa de fabricação de objetos adotada no processo produtivo instaurada na era moderna. $\mathrm{O}$ que antes da industrialização era produzido nas guildas ${ }^{1}$, onde a fabricação dos objetos eram elaborados por um único indivíduo, responsável pela concepção e confecção dos objetos, após esse período de transformação do processo produtivo, o trabalhado passa a ser fracionado; já que sobreveio a consolidação da separação entre as atividades de conceber das de fabricar objetos e, dessa forma, vai se estabelecendo o papel do profissional incumbido de preparar as instruções para a produção de bens.

Em termos de obtenção de escala, outra característica do design, ainda na antiguidade, a produção da joalheria, através da técnica de fundição por cera perdida ${ }^{2}$, já permitia atingir um aumento na quantidade de itens fabricados, mas nem por isso poderia ser identificada como uma atividade de design. Já possuía escala, isso é certo, mas não era uma produção na qual se separava a atividade de projeto da de fabricação, como tampouco havia outras características e etapas de projeto. Além disso, o surgimento do design está atrelado a um determinado contexto sócio-político e econômico, no qual se desenvolve e, ao mesmo tempo, se transforma até chegar a sua atual compreensão. Essa expansão do termo deu-se pela amplificação da sua aplicação, culminando na compreensão formulada nas primeiras décadas do século XXI.

O processo de transformação dos meios de produção se estendeu por um longo período; a depender da orientação do historiador, esse período pode retroceder até o século XI. De acordo com Cardoso (2008), um marco a

$1 \quad$ As guildas eram as organizações de trabalho na Idade Média.

2 Ver em "Metalurgia básica para ourives e designers: do metal à joia", de Andréa Madeira Kliauga e Maurizio Ferrante (2009). A fundição por cera perdida é uma técnica que teve início entre 4000-3000 a.C., sendo utilizada para a reprodução de objetos esculpidos em cera, atualmente se adota cera sintética, mas na antiguidade era usada uma mistura de cera de abelha com resina de arvores e óleo vegetal. Após esculpir a peça na cera, passa-se para a etapa do revestimento dos modelos de cera. Em seguida o revestimento é levado para uma estufa onde a cera é derretida, permanecendo apenas o molde em negativo. A próxima etapa é a fundição da liga metálica que, por fim, será vazada para o molde pré-aquecido. 
ser considerado foi à introdução da mecanização na imprensa, a qual ocorreu ainda no século XV. Porém, após essa primeira alteração, a imprensa foi, permanentemente, incorporando outras inovações no decorrer dos séculos XVII ao século XX. No entanto, foram, sobretudo, três grandes processos que deflagraram o surgimento do design: a industrialização, com sua organização dos meios de produção; a urbanização, com a concentração populacional; e, por último, a ampliação das redes de comércio, com uma grande aceleração na propagação dos seus mercados.

\begin{abstract}
A partir da metade do século XVIII, o processo de acumulação de velocidade para partida é tão nítido que historiadores mais velhos tenderam a datar a revolução industrial de 1760. Mas uma investigação cuidadosa levou a maioria dos estudiosos a localizar como decisiva a década de 1780 e não de 1760, pois foi então que, até onde se podem distinguir, todos os índices estatísticos relevantes deram uma guinada repentina, brusca e quase vertical para a "partida". A economia, por assim dizer, voava. (HOBSBAWM, 2005, p. 51).
\end{abstract}

Em referência aos resultados da industrialização para a economia, Hobsbawm (2005) usa o termo "partida" para denominar o período de intensas mudanças do poder produtivo das sociedades humanas, conhecida pelos economistas como "partida para o crescimento autossustentável". O conceito de liminaridade ${ }^{3}$, desenvolvido por Turner (1974), pode nos auxiliar na compreensão de certos fenômenos sociais. As revoluções são acontecimentos que não tem princípio e fim definidos; trata-se de um episódio que para romper com concepções prévias passa por um período liminar, momento ambíguo em que conviviam simultaneamente as ideias transgressoras junto com o ideário estabelecido e hegemônico. Nesse caso, a revolução industrial foi um período de transformações tão profundas que se estendeu por uma longa fase, cuja tarefa de precisar o espaço de duração já gerou muita controvérsia entre os seus estudiosos. No entanto, o que merece ser destacado é que como um fenômeno liminar, o que foi alterado depois se tornou estrutura, se transformou em norma. Ou seja, as transformações dos meios de produção foram, paulatinamente, sendo adotadas por outros setores e, dessa forma, foram vencendo os posicionamentos de resistência, como o do movimento Arts \& Crafts, que

3 A liminaridade tem como característica um espaço de ambiguidade, "uma vez que esta condição e estas pessoas furtam-se ou escapam à rede de classificações que normalmente determinam a localização de estados e posições num espaço cultural" (TURNER, 1974, p. 117). Nesse sentido, o espaço liminar não pertence nem a um campo, nem ao outro, ao mesmo tempo em que tem alguns aspectos de um campo e de outro, como se estivessem num limbo, sem pertencer ou poder ser classificados em uma posição ou outra. Em geral, a liminaridade é definida como espaços que se localizam nos interstícios da estrutura social, pois fogem das classificações dos campos que a influenciam. 
viam na introdução de mecanização e na produção em série a miséria do novo modelo de sociedade.

Portanto, a Revolução Industrial foi um dos acontecimentos mais marcantes para a história da humanidade, nele destaca-se a mudança nos meios de produção, aumento da escala, concentração da população em áreas urbanas e a expansão do mercado de bens de consumo. Como o design despontou a partir desses acontecimentos, seu surgimento está, portanto, relacionado a um determinado estágio da história do capitalismo e teve um papel fundamental na criação da riqueza industrial.

Mas isso não é tudo. O design além de estar relacionado ao lucro, tem se mostrado uma grande influência na nossa forma de pensar. De acordo com Forty (2007), é como se os "bens encarnassem os mitos". Para tal objetivo, é utilizado nos produtos um invólucro ou uma exterioridade que tenha o potencial de aludir a uma ideia. Todavia, para imprimir nos produtos essas ideias, é preciso está coadunado com os meios de produção disponíveis e com propostas que possuam apelo comercial. Nessa perspectiva, ao optar por uma determinada aparência, o design tem o poder de disfarçar ou "mudar a forma do que supomos ser a realidade"; daí essa capacidade que a atividade tem de encarnar mitos (FORTY, 2007, p. 21-40). Em cada momento, tem-se um vocabulário visual que domina a imagética de um período ou de um grupo social. Assim, o design se identifica com as escolhas da aparência das coisas, em consonância com as circunstâncias de sua produção e consumo.

A abordagem de Forty (2007) é histórica. Embora sua análise do design compreenda o período entre meados do século XVIII até meados do século $X X$, é, sobretudo, no século XIX quando o autor explora as distintas categorias de objetos, que corresponderiam às diferenças sociais. "Portanto, tomada em seu conjunto, toda a gama de bens manufaturados constituía uma representação da sociedade" (FORTY, 2007, p. 91). Assim, os reflexos dos aspectos formais têm uma forte influência na criação de uma realidade, pois o que o estudo do design confirma, para além da existência das distinções entre grupos sociais, é que as diferenças das categorias dos bens manufaturados ratificam "o que se pensava que eram essas diferenças sociais" (FORTY, 2007, p. 89-91). O autor chama atenção para os reflexos que a adoção de certas formas, associadas à ideologia hegemônica de um período, teriam para transformar a realidade. Nessa perspectiva, a chave para entender as mudanças no design é examinar o sistema social na qual eram usados os artefatos. Isso não significa que o design pudesse revelar as minucias das diferenças entre as classes sociais, até porque durante muito tempo na história da humanidade uma grande parcela da classe trabalhadora não tinha acesso aos bens de consumo; o que Forty (2007) destaca é que, na medida em que patrões passaram a comprar roupas e artigos para seus empregados, como os uniformes dos trabalhadores domésticos ou determinados tipos de chapéus, por exemplo, ficaram cada vez mais patentes as diferenças de classes. 
Contudo, para compreender as transformações pelas quais o termo design passou, mais atualmente, no sentido da expansão que a palavra design ganhou nos últimos anos, recorre-se às abordagens de dois filósofos contemporâneos, os quais tomam o design como objeto de suas reflexões: Oosterling (2009) e Sloterdijk (2003). De acordo com esse enfoque, também compartilhada por Latour (2009), a ampliação do termo tornou-se mais facilmente identificável devido à crise ecológica pela qual atravessamos, pois em decorrência dos elevados níveis de poluição a nossa existência precisa ser reelaborada. Em outros termos, tornou-se premente repensar o universo de objetos que nos cercam, a forma de construir casas, de produzir comida, eletrodomésticos, a busca pelo uso de energias renováveis, enfim, a forma de se estar no mundo precisa ser reconfigurada, levando o design a ter um papel central na construção dos espaços que habitamos. Destaca-se neste sentido, o surgimento de um novo paradigma para o design, o qual passa a implicar na maneira de olhar e se engajar no mundo. Dessa forma, esses filósofos contemporâneos argumentam que a ampliação do termo design está associada à própria concepção de criação de espaço para a nossa existência e, é nesse sentido, que a disciplina passa a ser tão crucial para pensar o homem, uma vez que para esses autores, o homem se constitui através da sua associação com objetos e ações. De acordo com Oosterling (2009), Sloterdijk (2003) posiciona a sua noção de 'esfera' na tradição de práticas artísticas, como a escultura social ${ }^{4}$ de Joseph Beuys, tendo como definição a citação abaixo:

"Neighbourhood, city, world - together, all these scales of publicness and publicity make up a layered gallery with no exit. The spaces between are not vacuums; they pulse with designed interactions and transactions" ${ }^{5}$ (OOSTERLING, 2009, p. 5, tradução nossa).

Nessa perspectiva, as coisas nos constituem e viabilizam a nossa existência, "[...] we account for ourselves via the media that surround and connect us, from automobiles to mobile phones"6 (OOSTERLING, 2009, p. 5, tradução nossa). Aqui vale atentar para a noção de 'coisa' adotada pela tradição da filosofia, da qual Sloterdijk e Oosterling fazem parte. Assim, o sentido de coisa não é a de um ente que nos é estranho, ou uma alteridade que nos é distante, ao contrário, as coisas parecem sair de nós mesmos e é isso que promove uma espécie de intimidade e familiaridade própria da relação de dois que formamos com essas coisas que afetamos e nos afetam.

$4 \quad$ A teoria da escultura social foi desenvolvida pelo artista alemão Joseph Beuys nos anos de 1970, no qual qualquer aspecto da vida pode ser apropriado como arte. Ele defendia que a vida era uma escultura social em que todos participavam da sua feitura (TATE, 2018).

5 Bairro, cidade, mundo - em conjunto, todas estas escalas de dimensão pública e de publicidade compõem uma galeria em camadas sem saída. Os espaços entre não são vazios; pulsam com as interações e transações projetadas.

$6[\ldots]$ nós nos damos conta de nós mesmos pela mídia que nos cerca e conecta, de automóveis a telefones celulares. 
Mais uma vez, as noções de sujeito e objeto não estão separadas. De maneira mais radical, o objeto é o ambiente, ou melhor, o espaço em que ocorrem as nossas ações. Segundo essa argumentação, da qual Latour (2009) também compartilha, não faz sentido separar sujeito e objeto, pois para os pensadores que romperam com essa gramática, o homem se constitui através da associação com as coisas, sendo esse o processo que possibilita a existência humana. Ou seja, o design foi tendo sua atuação expandida, à medida que os sistemas de suporte à vida foram se tornando cada vez mais explícitos ${ }^{7}$. Daí a relevância que a crise ecológica teve para revelar a fragilidade da existência e a necessidade humana de equipamentos que dão suporte à vida. Portanto, é neste sentido que a filosofia do design pode auxiliar na compreensão da própria transformação do sentido da palavra design e suas consequências para a vida.

\section{ONDAS DO DESIGN}

Para o filósofo que tem se dedicado à reflexão sobre o design, Henk Oosterling (2009), embora o design tenha uma brevíssima história, este campo de atividade já sofreu algumas mudanças. Ainda assim, a produção crítica da disciplina costuma retornar de forma recorrente para os mesmos temas, principalmente como: o papel do artesanato no design, a ambiguidade em sua relação com a arte ou a responsabilidade social e ética do designer. O autor observa alguns acontecimentos marcantes na trajetória do design, e seus reflexos na ação dos atores, entre as quais está o Arts $\&$ crafts, movimento que teve uma forte influência nas artes aplicadas, na criação de escolas de design e de arte. Passado esse primeiro momento, no qual as ideias críticas dos fundadores do movimento tiveram muita força, os designers tiveram interesse de desenvolver uma linguagem própria.

"After that, designers went in search of their own plastic and flexible language of forms, a kind of 3D visual syntax. Though their search was initially founded on values of craftsmanship, they eventually grudgingly accepted industrial values (OOSTERLING, 2009, p. 2, tradução nossa)" .

Outro momento do design, destacado por Oosterling (2009), surgiu em torno de 1960, quando a ênfase incidiu nos aspectos simbólicos. Ao se

$7 \quad$ Sloterdijk usa uma metáfora do cosmonauta no espaço sideral, que não sobreviveria sem o traje espacial, para demonstrar a necessidade de embalagens para a vida dos seres humanos. Nesse sentido os espaços são equipados com sistemas de suporte à vida.

8 Após isso, os designers foram em busca de sua própria linguagem de formas plástica e flexível, uma espécie de sintaxe visual 3D. Embora inicialmente a pesquisa tenha sido fundada nos valores do artesanato, só eventualmente aceitavam a contragosto valores industriais. 
associar à linguagem visual dos meios de comunicação, "o design passou a ser uma história", não precisava "ser útil para ser funcional" (OOSTERLING, 2009, p. 3). Para o filósofo, como o objeto passa a ter um status não importando a sua utilidade, a teoria da distinção de Bourdieu auxilia a entender esse momento, no qual os consumidores de cultura usavam produtos culturais para se distinguirem em seus grupos; mas claro esses grupos precisavam partilhar dos mesmos gostos, caso contrário, não valorizariam as nuances e peculiaridades características dos produtos. Em seguida, foi à fase da revolução digital; aqui a interatividade entre designers e usuários passou a ser a questão central. "Tecnicamente, PCs e Macs tornaram isso possível. Ideologicamente, a demanda por mais democracia e transparência fortaleceu o processo" (OOSTERLING, 2009, p. 2-4). Dessa forma, o design que é praticado a partir desse paradigma, fortaleceu a interação. A criatividade, que era um atributo necessário para a atividade do designer, foi deslocada para as relações entre produtores e consumidores e entre disciplinas. Para o autor, essas mudanças podem ser melhores compreendidas ao serem formuladas no formato de pergunta. Assim, o que antes era "Como deve ser sua aparência? passou para O que isso significa pra mim? até Como isso funciona entre nós?". Entretanto, uma mudança ainda mais atual e por isso mesmo ainda difusa, integraria o que Oosterling chamou de "design relacional" (OOSTERLING, 2009, p. 5).

A abordagem relacional do design é inspirada na filosofia de Sloterdijk, sobretudo, no aspecto pelo qual o autor apresenta o "design como o cerne de uma maneira diferente de olhar e se engajar com o mundo", em especial através de sua trilogia, a Esfera (OOSTERLING, 2009, p. 3). Nesta obra, o autor esboça uma teoria de mediação da coexistência, uma vez que os seres humanos não estão sós no mundo, mas estão envolvidos pelo 'outro', em uma relação diádica, onde a unidade é formada por dois seres. Nesse sentido, mesmo se pensássemos uma situação extrema, como a de um homem no deserto, homem e o deserto formariam uma unidade. Para ilustrar a relação diádica que formamos com os outros seres, Sloterdijk (2003) usou a Figura 1, do pintor inglês, Sir John Everett Millais (1829-1896), para mostrar que o outro seria como a bolha da pintura e, portanto, é produto da ação da criança, não se tratando de uma alteridade que lhe cause uma estranheza; ao contrário, é um outro que saiu dele mesmo, a afeta por suas características de leveza e airosidade e, ao mesmo tempo, é afetado por ele, por sua ação. Neste sentido cada ator é um meio, ou um ser de alta permeabilidade. 


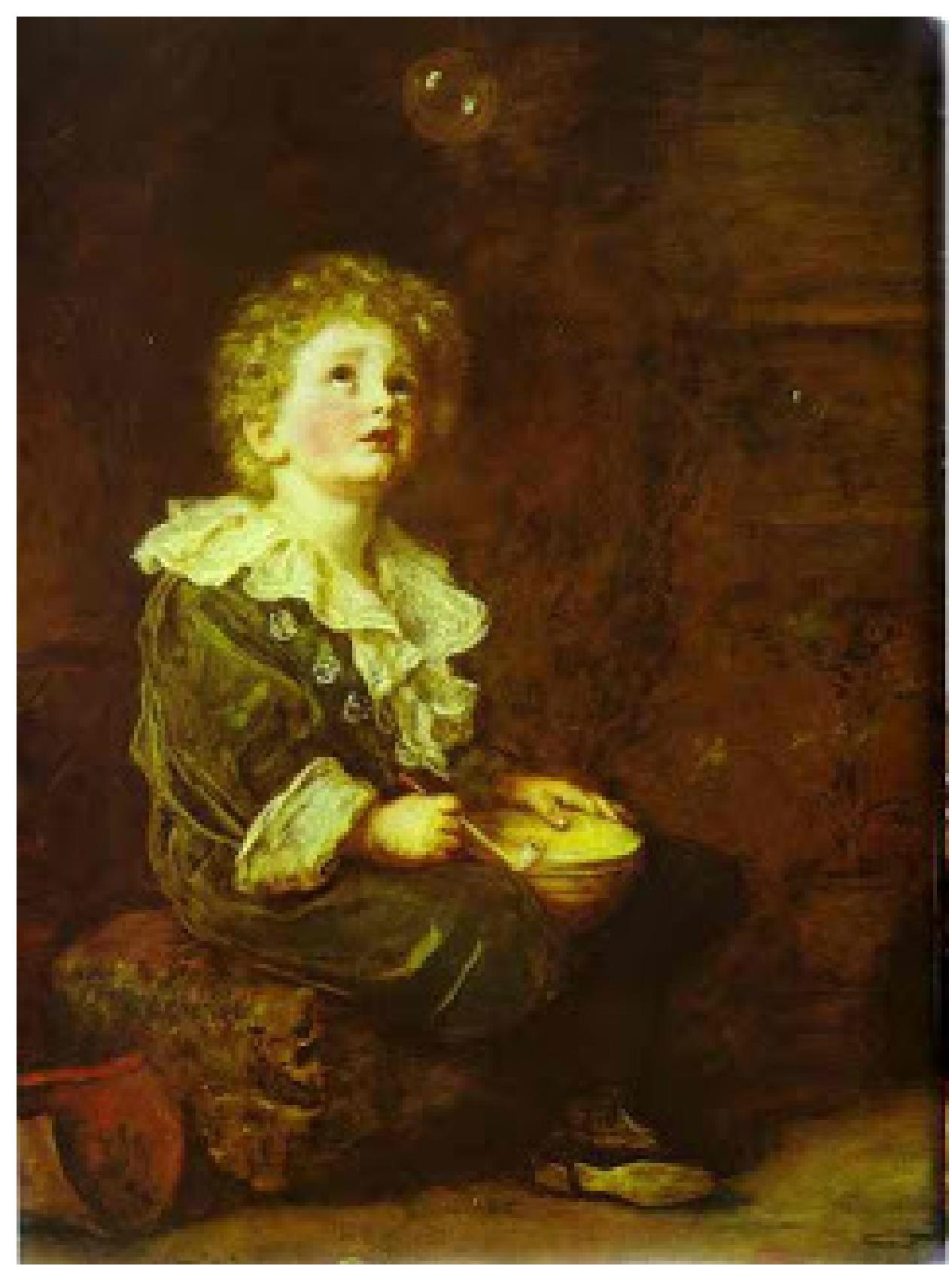

Fonte: National Museums Liverpool (2018).

De acordo com Oosterling (2009), Sloterdijk argumenta que nos últimos duzentos anos o conceito moderno de escassez, liberdade e autonomia, sofreram mudanças substanciais. Nas palavras do autor: vai ser o princípio de abundância, introduzido pela intensificação da produção em massa e pelos estímulos ao consumo, que será o ponto de partida para a ação e o pensamento.

Over the last two centuries, the modern concept of scarcity has been turned inside out, as have those of freedom and autonomy. Once, freedom meant independente selfdetermination; nowadays, it means claiming the right to limitless mobility and the festive wasting of energy. Media are essential in this. We depend on them. Westerners live

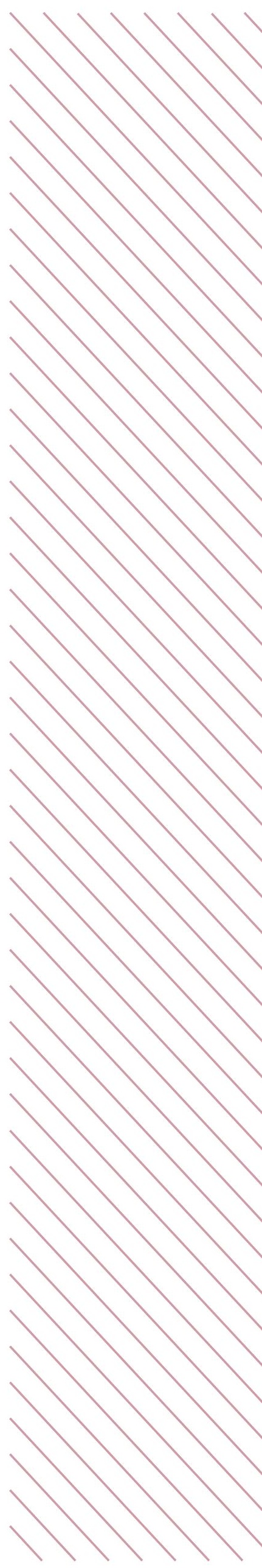


in a world of too much. Shopping and consuming are our biopolitical duties as citizens, to which we are called in times of emergency such as terror attacks and credit crises. Go forth and buy! [...] In everyday life, the decision to buy an item is driven more by fear and the need for identity than by inter-esse and belonging. Every Dasein is styled through the consumption of design. Without design, Dasein ${ }^{9}$ is meaningless ${ }^{10}$ (OOSTERLING, 2009, p. 4, tradução nossa).

A partir dessa perspectiva, destacam-se dois aspectos nos quais a filosofia de Sloterdijk se mostra interessante para pensar o design. O primeiro aspecto é pensar o mundo em sua relação entre os seres humanos e os objetos; nessa chave de pensamento, o homem nunca está só, a unidade é sempre de dois. O outro aspecto é por ele ser um pensador do espaço íntimo, não no sentido de uma interioridade do sujeito, mas da necessidade humana de criar espaço interior habitável, na forma de um receptáculo, que surge da própria intervenção do indivíduo. Melhor dizendo, surge da necessidade humana de imprimir sua feição no mundo, permitindo-o, dessa forma, a possibilidade de ser habitado. Mas para chegar a essa formulação, Sloterdijk precisou romper com a separação entre sujeito e objeto, pois essa abordagem não permitiria descrever o que se passa em uma relação diádica, entre os seres humanos e, portanto, não seria possível formular a fenomenologia do espaço íntimo. Não estamos sós no mundo, ao contrário, somos acompanhados por outros, os quais podem ser compreendidos por comporem uma familiaridade com o espaço habitado. Em outros termos, de acordo com essa argumentação, o outro não é uma alteridade que nos surpreenda; ao contrário, o outro parece sair do próprio indivíduo, reforçando, desse modo, a existência de uma familiaridade e, por conseguinte, da própria noção de espaço interior. Como herdeiro do pensamento de Nietzsche e Heidegger, Sloterdijk toma como uma de suas

$9 \quad$ Ver: "A cautious Prometheus? A few steps toward a philosophy of design (with special attention to Peter Sloterdijk)", de Bruno Latour (2009). Latour explica que Sloterdijk adota o conceito de Dasein, extraído da obra de Heidegger, cujo sentido pode ser traduzido por existência. Mas a diferença central entre as duas argumentações, é que uma adota a gramática sujeito/ objeto, e a outra propõe um rompimento desse modelo. Para Sloterdijk, não existe condicionantes materiais, de um lado, e condicionantes humanos e simbólicos, de outro. Ao contrário, criamos os espaços, tanto internos, quanto externos, que sejam equipados com sistemas que nos permitam viver.

10 Ao longo dos últimos dois séculos, o conceito moderno de escassez foi virado ao avesso, assim como, os de liberdade e autonomia. No passado, liberdade significou independente de autodeterminação; hoje em dia, esse termo significa reivindicando do direito ilimitado de mobilidade e de desperdício festivo de energia. Mídia são essenciais neste processo. Nós dependemos delas. Os ocidentais vivem em um mundo de muito. Comprar e consumir são os nossos deveres como cidadãos biopolíticos, para os quais somos chamados em momentos de emergência, tais como: ataques terroristas e as crises de crédito. Vá em frente e compre! [...] Na vida cotidiana, a decisão de comprar um item é impulsionada mais pelo medo e pela necessidade de identidade do que pelo interesse e pertencimento. Todo Dasein é denominado através do consumo de design. Sem design, Dasein não tem sentido. 
questões, pensar a transformação operada em um ser selvagem, para se tornar um ser domesticado. Para responder a essa questão, o autor vai se alinhar aos pensadores que se ocupam em pensar que 'o homem é fundamentalmente aquele que se autoproduz'. A resposta marxista, por exemplo, também vai nessa direção; no entanto, para a teoria marxista a resposta é a de que o homem se autoproduz no trabalho. Dessa maneira, trabalho e homem são quase um produto único.

Para Bruno Latour, "Sloterdijk abordou a ampliação da compreensão e da extensão da noção de design desde muito cedo e muito literalmente" (LATOUR, 2009, p. 8, tradução nossa):

"Human are to be handled with infinite precaution from the womb (natural or artificial) in which they are grown (Sloterdijk defines philosophy as a kind of obstetrics!) all the way to the place where they survive and die"11.

Nesta perspectiva, Sloterdijk adota a mesma argumentação que Latour (1994) usou no livro "Jamais fomos modernos"; qual seja, a de ultrapassar as duas narrativas que, segundo o autor, formariam a modernidade, segundo a qual, de um lado, se encontrava a narrativa, por ele chamada de attachment ou anexada, acessória e escondida, na qual há a produção de híbridos e, de outro lado, a história oficial da emancipação, que busca através da purificação ${ }^{12}$ criar duas ontologias distintas, uma para humanos e outra para não-humanos. Neste ponto, o pensador alemão concorda com Latour e defende que as duas narrativas fazem parte de uma única história. Latour (1994)complementa essa ideia ao destacar que a unificação das duas narrativas ocorre quando se modifica profundamente o sentido do que é o ser "no mundo", ou na relação em que o homem estabelece com o espaço por ele habitado, tal como o cosmonauta que se libertou da dependência da gravidade, sem a qual ele não resistiria uma fração de segundo, através da conexão com um artefato. Segundo Latour (1994), as duas narrativas engendradas pela modernidade, associação e emancipação, são

11 Humanos devem ser tratados com infinita precaução desde o ventre (natural ou artificial), na qual eles são criados (Sloterdijk define como uma filosofia tipo de obstetrícia!) todo o caminho até o lugar onde sobrevivem e morrem.

12 Ver em "Jamais fomos modernos" (LATOUR, 1994). A purificação faz parte da prática da crítica. Crítica aqui é entendida como o conjunto de conhecimentos nos quais se opera o tratamento de separação dos híbridos. Latour trabalha com a hipótese de que o termo moderno cria dois conjuntos de práticas diferentes: de um lado cria os híbridos, também chamados de redes, nas quais há a mistura de natureza e cultura; por outro, por purificação, cria duas ontologias distintas, uma para os humanos e outra para os não-humanos, a qual é denominada de crítica. Latour chama atenção para a diferenciação dos repertórios que os críticos utilizam para falar do mundo. Nesse sentido, o autor cita Changeux com a naturalização, Bourdieu com a socialização e Derrida com a desconstrução. Embora essas críticas sejam potentes, são de tal forma incompatíveis que não podem ser combinadas. De forma irônica, Latour afirma que os epistemólogos, sociólogos e desconstrutivistas precisam ser mantidos afastados, "alimentando sua crítica com as fraquezas das outras duas abordagens" (LATOUR, 1994, p. 11). 
duas encarnações do mesmo evento, passíveis de observação, contanto que se atente para o modo como as atmosferas artificiais são bem ou mal projetadas.

\subsection{Expansão do Design}

Latour (2009) compartilha os pressupostos de Oosterling e Sloterdijk, ao analisar o design. Dessa maneira, argumenta que o sentido da palavra sofreu uma importante ampliação em termos de compreensão e extensão, comparado ao que ele conhecia quando jovem. Para desenvolver essa argumentação, Latour compara o entendimento que tinha do design na sua juventude, com a dimensão que o termo ganhou na atualidade. Assim, para o autor, o design, antes, era visto como uma qualidade a mais agregada aos objetos, não passava de um invólucro para as funcionalidades dos objetos. A ideia central para o autor referese à ampliação que o termo design passou a abarcar. Latour (2009) recorre ao exemplo do iPhone, o qual passou a envolver muitas funções, tais como: planejar, calcular, organizar, embalar, acondicionar, definir, consertar, escrever em código, e assim por diante. Assim, essa extensão ocorre em referência à ampliação do conjunto de coisas que passaram a ser projetadas. O que antes era concebido como um papel secundário do design visto ser um campo que se ocupava com os acabamentos que os bens deveriam adotar, mesmo que esses bens fossem eficientes; agora, a disciplina ganhava outra dimensão, "passou a adquirir importância para o cerne da produção" (LATOUR, 2009, p. 1-2). Em outros termos, o design deixava de se ocupar com a aparência das coisas projetadas por engenheiros e cientistas, passando a atuar em outros universos, tais como: cidades, paisagens, nações, corpos, genes, e conforme Latour vai defender, até mesmo na própria natureza.

A tese de Latour (2009), é que essa ampliação do design é um reflexo da mudança que se operou na forma como interagimos com os objetos. Ou seja, a expansão do que passou a ser abarcado pelo design transformou a forma como lidamos com objetos e ações de modo geral. Latour relaciona essa modificação com o argumento que defendeu no seu livro "Jamais fomos modernos", no qual ele discute, em última instância, a separação entre natureza/matéria e cultura/design como consequência de dois conjuntos de práticas diferentes, características do modernismo (LATOUR, 1994, p. 11-17). Latour vai além e diz que a palavra design está substituindo a palavra revolução, na medida em que tudo tem que ser projetado, inclusive a natureza. De acordo com Latour (2009), a amplitude da palavra design é mais um indicativo de que já nem acreditamos mais que fomos modernos, na medida em que evidencia que não há separação entre sujeitos e objetos. Portanto, à medida que se pensa que somos designers, na acepção proposta pelo autor, menos nos entendemos como modernos (LATOUR, 2009, p. 1-2). De novo, através do termo design vai-se gradualmente dissolvendo a separação entre matéria e objetos de design. A comparação da palavra design com a adoção da palavra revolução em momentos de ruptura 
de paradigma é sugerida para reforçar a artificialidade e construção do universo que nos cerca a partir do design. É como se tudo passasse a ser construído, evidenciando que formamos híbridos com os objetos.

Para Latour (2009), são cinco as vantagens do conceito de design. Primeiro no design não existe a ideia de fundação, apenas de incrementos, pois funcionaria como acréscimos à materialidade ou às funções dos objetos cotidianos. A segunda, e talvez mais importante implicação do design, refere-se à atenção aos detalhes. Portanto, o autor, destaca que a conotação chave no design, para além da modéstia, é o senso de perícia, artesanato e atenção obsessiva aos detalhes. A terceira conotação da palavra design refere-se ao significado - seja em conotação simbólico, comercial, ou outra - que se emprega ao analisar o projeto de algum artefato. Portanto, o design é feito para ser interpretado na linguagem dos signos.

Latour (2009) acrescenta que em sua definição mais frágil, design adiciona apenas sentido superficial ao que era matéria bruta e eficiência. À medida que se atinge outros níveis do objeto, se traz uma nova atenção ao significado. Sempre que se pensa em algo que foi projetado, aportam-se todas as ferramentas, habilidades e ofícios de interpretação para a análise dessa coisa. Neste sentido, Latour diz que, pensar as coisas em termos de design é se afastar da concepção modernista de objetos, e concebe-los mais como coisas.

O quarto recurso da palavra design ressalta a característica de um processo que nunca começa do zero: projetar é sempre redesign. Parte de uma coisa que existe como um dado, como uma questão, como um problema. "To design is never to create ex nihilo" (LATOUR, 2009, p. 5). Nesse sentido, há um abismo entre criar e design. $O$ que demonstra que para o autor a criação não partiria de uma questão, mas não é o que se observa nas atividades criativas, de modo que aqui fica uma dúvida, pode-se falar de criação sem um problema ou a partir de uma tabula rasa? De toda forma, o redesign é uma qualidade do processo de design, pois a depender do projeto, uma das etapas é a pesquisa dos similares. Porém, o que merece ser destacado neste recurso é uma atitude reparatória, pois a atividade que se ocupa em alterar algo para que se torne mais sustentável, mais comercial, ou mais intuitivo, sinaliza uma fragilidade e contrasta com outras áreas entendidas como 'mais sérias', como a engenharia ou a ciência. "Designing is the antidote to founding, colonizing, establishing, or breaking with the past. It is an antidote to hubris and to the search for absolute certainty, absolute beginnings, and radical departures"13 (LATOUR, 2009, p. 5, tradução nossa).

O quinto e decisivo recurso do conceito design, refere-se, necessariamente, à dimensão ética, a qual está vinculada à questão óbvia do bom versus o mau design. No estilo modernista, essas questões, do bom versus o mau design,

13 Projetar é o antídoto para fundar, colonizar, estabelecer ou romper com o passado. É um antídoto à arrogância e à busca de certeza absoluta, princípios absolutos e partidas radicais. 
referiam-se a qualidades que as "matérias de fato" não poderiam possuir. Sobre a matéria, não há nenhum julgamento possível; é apenas um fato a ser revelado. A propagação do design para o interior da definição das coisas traz consigo, não só significado e hermenêutica, mas também moralidade. Mais exatamente, é como se materialidade e moralidade tivessem finalmente se aglutinado, se unido. As consequências dessa premissa são de grande importância porque ao se começar a redesenhar cidades, paisagens, parques naturais, sociedades, assim como genes, cérebros e chips, nenhum designer poderá se esconder atrás da velha proteção da matéria de fato/natureza. Ou a supor e afirmar que estariam apenas atestando o que existe. Dessa forma, para Latour (2009), o design, ao se expandir, não vai poder se esconder atrás da materialidade ou sob as "questões de fato"; precisará enfrentar as questões morais. Conforme Latour (2009), defende em outros trabalhos e reitera neste artigo, nos estudos sobre ciência e tecnologia (ECT), os cientistas também transformaram objetos em projetos, trouxeram sentido ao que era definido como mera limitação material, assim como também contestaram os argumentos da forma versus a função, além de transformarem "matérias de fato" em associações complexas e contraditórias de seres humanos e não-humanos conflitantes. Mostraram, portanto, que os artefatos têm políticas.

Latour (2009) lança um questionamento aos designers sobre onde estariam as ferramentas de visualização que vão permitir que a natureza controversa e contraditória da "matéria de interesse" possa ser representada? Por representação incluem-se as técnicas de representação artísticas, científicas e políticas. Assim, sua proposta é que haja uma ferramenta de visualização para coisas desenhadas juntas - coisas e humanos. E se pergunta por que os poderosos vocabulários visuais que puderam ter sido utilizados no passado por gerações de artistas, designers, filósofos e ativistas da "matéria de fato", e não possa ser reeditado para a representação das "matérias de preocupação"?

\section{CONCLUSÃO}

Após essa breve reflexão sobre a trajetória do design, em que destacouse o contexto de origem da atividade, passando por abordagens que tratam de compreender as transformações pelas quais o termo design sofreu na atualidade, identificou-se, simultaneamente, mudanças nos nossos modos de ser e estar no mundo.

Pode-se dizer que, para Sloterdijk (2003) a história das civilizações foi à conquista do exterior, do fora. Os espaços exteriores habitados constituem uma tentativa de formar uma díade com esse exterior estranho. A chave para formar díades é criar sistemas de imunização; assim a narrativa da espécie humana é a tentativa de domesticação do espaço externo. É nesse sentido que nos parece 
tão interessante a argumentação de Sloterdijk, pois a partir do século XVIII a tecnologia adquire uma preeminência e é usada para traduzir o exterior que nos é hostil.

Oosterling (2009), estudioso de Sloterdijk, cujo foco de interesse é o design desenvolvido na atualidade, no século XXI, destaca que a forma como nos relacionamos com o mundo atual, aponta para transformações geradas pelas "mídias", termo que o autor utiliza para se referir aos objetos que nos constituem ou o mundo material que nos envolve. Esses objetos estão tão intimamente relacionados com os atores, que afetam a maneira como atuamos no mundo. Em outros termos, para Oosterling (2009), a forma como estamos no mundo é afetada pelas "mídias", as quais mudam a nossa maneira de agir e atuar, a ponto de termos que desenvolver habilidades para participar do mundo. Não só as nossas ações, mas também o pensamento é intermediado pelo mundo material que nos cerca. Com a crise ecológica, fruto da utilização massiva das riquezas naturais para a produção de bens industrializados, outras propostas são pensadas para o design. Em suma, apenas com o intuito de introduzir brevemente as reflexões filosóficas sobre o design, conclui-se essa comunicação com a seguinte consideração: se concordamos que o design contribui para entender a maneira na qual estamos e pensamos o mundo, o design também seria dotado de atributos para mudar a vida em grupo? 


\section{REFERÊNCIAS}

CARDOSO, Rafael. Uma introdução à história do design. São Paulo: Blucher, 2008.

FORTY, Adrian. Objeto de desejo: design e sociedade desde 1750. São Paulo: Cosac Naif, 2007.

HOBSBAWM, Eric John Ernest. A era das revoluções: Europa 1789-1848. São Paulo: Paz e Terra, 2009.

KLIAUGA, Andréa Madeira; FERRANTE, Maurizio. Metalurgia básica para ourives e designers: do metal à joia. São Paulo: Blucher, 2009.

LATOUR, Bruno. A cautious Prometheus? A few steps toward a philosophy of design (with special attention to Peter Sloterdijk). In: ANNUAL

INTERNATIONAL CONFERENCE OF THE DESIGN HISTORY SOCIETY, 2008, Falmouth, MA. Proceedings... Irvine, CA: Universal Publishers, 2009. E-books, p. 2-10.

LATOUR, Bruno. Jamais fomos modernos: ensaio de antropologia simétrica. Rio de Janeiro: Ed. 34, 1994. 
NATIONAL MUSEUMS LIVERPOOL. Artwork details. Disponível em: $<$ http://www.liverpoolmuseums.org.uk/picture-of-month/displaypicture. aspx?id=299>. Acesso em: 11 jan. 2018.

OOSTERLING, Henk. Dasein as design or: must the design save the world? Melintas, Bandung, v. 25, n. 1, p. 1-22, 2009. Disponível em: <http://journal. unpar.ac.id/index.php/melintas/article/viewFile/930/914>. Acesso em: 11 jan. 2018.

SLOTERDIJK, Peter. Esferas I: burbujas. Madrid: Siruela, 2003.

TATE. Social sculpture. Disponível em: <https://www.tate.org.uk/art/artterms/s/social-sculpture>. Acesso em: 11 jan. 2018.

TURNER, Victor Witter. O processo ritual: estrutura e anti-estrutura. Petrópolis: Vozes, 1974. 